\title{
A Survey to Recognize the Most Important Dimensions of the Service Quality of Iran's Commercial Banks
}

\author{
Mohamad Reza Ebrahimi (Corresponding author) \\ Faculty of Management and Accounting, Shahid Beheshti University, Tehran, Iran \\ E-mail: Mrebrahimi61@yahoo.com
}

Akram Hadizadeh Moghadam

Faculty of Management and Accounting, Shahid Beheshti University, Tehran, Iran

E-mail: Hadizadeh6@gmail.com

Received: May 30, 2012

Accepted: July 17, 2012 Published: October 1, 2012

doi:10.5296/jmr.v4i4.1870

URL: http://dx.doi.org/10.5296/jmr.v4i4.1870

\begin{abstract}
To achieve customer satisfaction, banks need to recognize the most important dimensions of service quality. The main target of this research is to recognize the dimensions which are more important for the customers. In this regard, a variety of models and researches were analyzed to develop the conceptual model of this research. This model was then modified by banking experts and university lecturers of the field. The Statistical population of this research includes customers in ten different commercial banks in ten different provinces of the country. This population was classified based on the provinces and banks and then customers were taken from each class randomly. Finally, 555 questionnaires were collected. To analyze the data, ANOVA and Correlation techniques were conducted by SPSS software. Findings indicate that Assurance is the most important factor and being based on the principles of Islamic Banking is the least important factor for the customers.
\end{abstract}

Keywords: Customer Expectations, Service Quality, Tangibles, Assurance, Empathy, Reliability, Responsiveness, Islamic Banking 


\section{Introduction}

Iran's Banking Industry has experienced some challenges in this decade. First of all, there used to be only public banks in the industry. But, during this decade, some private banks joined the industry. On the other hand, some public banks, like Tejarat and Saderat, were privatized. Finally, some new financial institutions and private banks have joined the industry. All aforementioned factors have changed the nature of the industry dramatically. Therefore, it is necessary to know what the expectations of customers are, which dimensions of service quality are more important and how far Iran's banking industry can meet customers' expectations and demands. This research intended to find out the answers of these questions.

\section{The concept of Customers' Expectations}

Coye (2004) states the concept of expectations is defined in two ways. The first definition focuses on behavior. An expectation is the subjective probability that a behavior will be followed by a particular outcome. More broadly, expectations reflect an individual's subjective probabilities about the current or future existence of a particular state of affairs. (Coye, 2004)

Coye then states there is considerable variation in the definitions of expectations. Zeitmal et al maintain that two principal conceptualizations of expectations exist. The first holds that "expectations are viewed as predictions made by customers about what is likely to happen during an impending transaction or exchange" (Zeithmal \& Bitner, 1996). This definition -predictive expectations- is consistent with the classic notion of expectations. Alternatively, the term expectation has been used to represent what customers ideally want -normative expectations.

\section{The concept of Service Quality}

In management literature, Service is usually defined as a process in which something intangible is offered. In most countries, the services sector of the economy is dramatically growing. (Najari, 2003)

Services have some characteristics which makes them different from goods:

1) Intangibility of services

2) Inseparability of time and place

3) Services are more difficult to control

4) Services cannot be stored

5) Services cannot be owned during the process of selling (Woodruffe, 1995)

Chang (2004) states that Parasuraman et al. $(1985,1988)$ conducted numerous studies to identify the service quality attributes that can influence customers' perception of the quality. The five dimensions that were identified are briefly described below: 


\section{Macrothink}

- Reliability: The fulfillment of the promises made by the service provider to the customer such as providing the appropriate service promptly.

- Responsiveness: The employees' prompt and willing reaction to the needs of the customers.

- Assurance: the employees' level of courtesy and knowledge.

- Empathy: the service provider's demonstration of its concern for the individual needs of customers.

- Tangibles: The appearance of facility and personnel.

Parasuraman et al. (1988) then utilized these five dimensions as the guiding framework to develop SERVQUAL -a survey instrument that consists of 22 items that are designed to measure service quality.

In this research, the basic model of SERVQUAL has been developed by adding Islamic Banking to the model as the sixth factor. Since according to Iran's laws all the banks have to act based on Islamic Principles, the sixth factor as one of the important attributes of the service quality has been added to the model. Islamic Banking can be briefly defined as follows:

- Islamic Banking: There are three important factors which distinguish Islamic Banking from Non-Islamic Banking;

1) Banking contracts should be based on the Islamic principle of earning no extra Interest (in Islam called Riba)

2) Banks' Interest rate for different banking accounts should be calculated based on Islamic principles to avoid getting or giving Riba.

3) Banking facilities should be controlled to be spent based on Islamic principles. (Mosavian, 2008)

On the other hand, the 22 items introduced by Parasuraman et al. (1988) were expanded to a questionnaire containing 41 items. The expanded model and questionnaire were then analyzed by several university teachers and banking experts to be modified and confirmed to be used in this study.

This study aims to recognize which of these items are more important for Iranian customers. Therefore, the basic model of this study is developed as shown in figure 1.

\section{Research Questions}

The main target of this study to answer these questions:

1. Based on customers' expectations, what are the most important dimensions of service quality in Commercial Banks of Iran? 


\section{Macrothink}

Journal of Management Research

ISSN 1941-899X

2012, Vol. 4, No. 4

2. Based on customers' expectations, for each single dimension, what are the most important factors?

3. How far customers' expectations of each factor are met?

\section{Research Hypotheses}

The hypotheses of this survey are mentioned below. Since customers are expected to choose their answers for the questions out of 5 we consider ratings above 2.5 to be high ratings.

H1: The bank customers will give high ratings to the banks in terms of the importance of Tangibles.

H2: The bank customers will give high ratings to the banks in terms of the importance of Reliability.

H3: The bank customers will give high ratings to the banks in terms of the importance of Responsiveness.

H4: The bank customers will give high ratings to the banks in terms of the importance of Empathy.

H5: The bank customers will give high ratings to the banks in terms of the importance of Assurance.

H6: The bank customers will give high ratings to the banks in terms of the importance of Islamic Banking.

\section{Methodology}

This study aims to recognize the most important dimensions of service quality of Iran's Commercial Banks. In this regard, a questionnaire containing 41 questions was applied. In the table 1 , these 41 items are mentioned.

Customers were requested to choose their answers for each question out of five, as illustrated below.

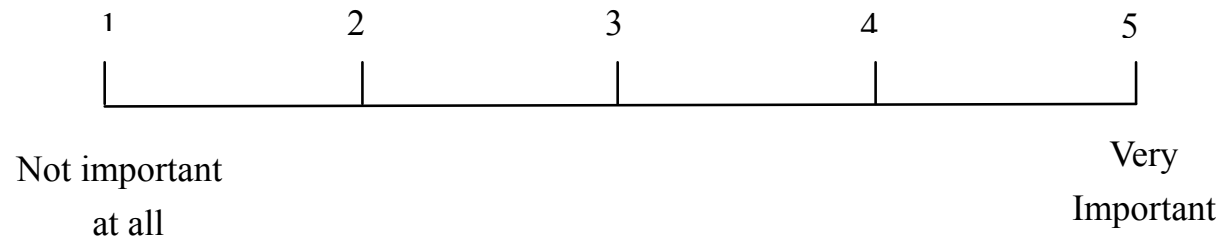

To evaluate the reliability of the questionnaire, Chronbakh Alpha was calculated based on the following formula:

$$
\alpha=\left(\frac{j}{j-1}\right)\left(1-\frac{\sum S_{j}^{2}}{S^{2}}\right)
$$




\section{Macrothink}

Journal of Management Research

ISSN 1941-899X

2012, Vol. 4, No. 4

This is a common technique which is normally used for the studies which gather data by questionnaire. In this formula " $\mathrm{j}$ " represents the number of questions and "S" represents the Variance. If Alpha becomes more than 0.70 the questionnaire is reliable enough. (Sarmad, 2002)

Therefore, thirty questionnaires were distributed and then, using SPSS software, Alpha was calculated. The result of this calculation, 0.936 for Alpha, proved that the questionnaire is reliable enough.

To calculate the reliability of the interview, the content analysis method was applied. In this method, two interviewers do the interview and try to codify the answers. Then they compare their codes to find out how many similar codes they have found in the answers. In the following formula, $\mathrm{M}$ indicates the total number of codified answers which both interviewers agreed on. N1 and N2 indicate the number of codified answers by the first and second interviewer respectively: $\quad \frac{2 M}{N 1+N 2}$

In this study, two PhD students as interviewers conducted three interviews and codified the answers.

As illustrated in table 2, for all interviews we got to ratings more than $90 \%$ which indicates high reliability of the interviews. These codes were then used to recognize the dimensions of service quality better and enrich the questionnaire of this survey.

\section{Sampling}

The Statistical population of this research includes customers in ten different commercial banks in ten different provinces of the country. This population was classified based on the provinces and banks and then customers were taken from each class randomly.

Finally, 555 questionnaires were collected. To analyze the data, ANOVA and Correlation techniques were conducted by SPSS soft ware.

In table 3, the number of branches of each bank has been mentioned based on the latest published data by Iran's Banks Data Base. (Iran's Banks data base, 2010)

Since the statistical population of this study is considered to be unlimited, the following formula was applied to calculate the desired sample.

$$
n=\frac{Z_{\frac{\alpha}{2}}{ }^{2} p q}{d^{2}}
$$

So, with $0.04 \%$ accepted error, and 1.96 assurance level, we got to desired sample which is 600 .

$$
n=\frac{(1.96)^{2}[(0.5)(0.5]}{(0.04)^{2}}=600
$$


Then, we needed to distribute 600 questionnaires in ten different provinces of the country in ten different banks. To choose these ten provinces we referred to the latest published data by Iran's Statistics Organization and then we chose the top ten most populated provinces as follows: (Iran Statistics Org, 2008)

\section{Data Analysis}

The desired sample was 600 but due to some limitations like lack of cooperation of some branches and long geographical distances there finally 555 questionnaires were gathered. They were then analyzed using descriptive and deductive statistics. We then used Structural Equation Modeling and Confirmatory Factor Analysis.

\section{Demographic Analysis}

In this survey, $65 \%$ of the respondents were male and the rest were female. This is simply because men spend more time out of home working. Also, around $42 \%$ of the respondents were single, $53 \%$ married and the rest did not complete this part of the form.

\section{Correlation Analysis}

In table 5, the correlation of the factors of the model is shown. Based on the table, most factors in the model have significant correlation.

\section{Mean Analysis}

In table 6, the ratings for the level of importance of each factor and also the level of meeting customers' expectations are shown. These ratings are out of five. Basically, we can infer from this table that, for all factors the expectations of customers are not fully met which was quite predictable. The most interesting part of the findings of this survey is that Islamic Banking has got the lowest ratings for both the level importance and the level of meeting expectations. This simply means, for the Iranian customers in this survey, being based on Islamic Principles is the least important factor in service quality. On the other hand, it indicates that in comparison to other factors of service quality, Islamic Banking has met customers' expectations the least.

Now, we can come to some conclusions about the hypotheses of this survey. In table 7, the final result is shown.

\section{Conclusion}

Among service dimensions, Assurance and Responsiveness are the most and Islamic Banking is the least important factor for the customers but according to Iran's laws, all the banks have to provide their services based on the Islamic principles and no bank is allowed to provide non-Islamic banking services.

Considering the level of meeting customers' expectations, Assurance and Reliability got the highest ratings.

The noticeable point is that in this survey Islamic Banking was recognized to be the least important factor for customers. On the other hand, this factor got the lowest ratings in terms 
of meeting customers' expectations which simply means Iranian customers believe banking services are not that much based on rules of Islam.

In terms of Tangibles, Suitable waiting hall for the customers and physical distance of the branch are more important for the customers. These findings almost cope with the findings of Johnston (1997). In his survey, Suitable waiting hall for the customers and the beauty of the interior design got the highest ratings.

In terms of reliability, Fulfillment of promises and Suitable ATM machines are more important for the customers. Parassuraman (1988) and Ho (2004) had emphasized the importance of keeping promises by banks in their studies. Also, Leighan and Megha (2008) had found that ATM machines are very important for Canadian customers.

In terms of Responsiveness, The ability to answer customers' questions properly and having few formalities are more important for the customers. The importance of these factors had been discussed in the studies of Gronroos (2000), Chang (2007) and Dutta (2009).

In terms of Assurance, Confidence in employees and Courtesy are more important for the customers. The importance of these factors had been discussed in the studies of Gronroos (2000), Chang (2007) and Dutta (2009). Also, Parassuraman (1988) and Johnston (1997) had highlighted these factors in their studies. Moreover, Lai (2006) and Heffernan (2008) had got to the same result in their studies of the services of banks in Taiwan and Australia.

In terms of Empathy, Delivering services without mid-day stops and suitable working time of the banks (suitable start and closing time) are more important for the customers. Parassuraman (1988) had emphasized the importance of suitable working time in his studies.

In terms of Islamic Banking, Riba-free banking contracts and Controlling bank facilities based on Islamic principles are more important for the customers. These findings cope with the findings of Kamal (1997) who had emphasized being Riba-free is an important characteristic of Islamic banks.

\section{References}

Chang, Hsing Chang. (2007). Customer expectations of the Taiwan Banking industry, Nova southern University, USA.

Coye, Ray W. (2004). Managing customer expectations in the service encounter. International Journal of Service Industry Management, 15, 1.

Dutta, Kirti. (2009). Customer expectations and perceptions across the Indian Banking Industry and the resultant financial implications. Journal of Services Research, 9(1).

Gronroos, Christian. (2000). Service Management and Marketing. John Wiley Sons

Heffernan, Troy and et al. (2008). Relationship marketing, the impact of emotional intelligence and trust on Bank performance.

HO, Teck H., \& Zheng, Yu-sheng. (2004). Setting customer expectation in service delivery. 
Fitzsimmons, James A., \& mono J. FitzSimmons. (1994). Service marketing for competitive advantage. Printedin Singapore: Mc Graw_Hill Inc, $1^{\text {st }}$ Ed, chap9, p195.

Iran's Banks Data Base. (2010). Kanoon Etela Resani Shahr Publications, Ed 3.

Johnston Robert. (1997). Identifying the Critical Determinants of Service Quality in Retail Banking: Importance and Effect. International Journal of Bank Marketing, 5(4), 111-114.

Kamal, Naser. (1997). Strategic marketing management: the case of Islamic banks. International Journal of Bank Marketing, p 187.

Lai, Shu Fang, Hsiao, Ying-Chien, Yang, Yi-Feng, Huang, Yuan-Chih, \& Lee, I-Chao. (2009). The mediating influence of service Quality satisfaction and information trust on the eCRM process moder. The Journal of American Academy of Business, Cambridge, 15.

Leighan C.Neilson, \& Megha Chadha. (2008). International marketing strategy in the retail banking industry: The case of ICICI Bank in Canada. Journal of Financial Services Marketing, 13, 204-220, 2008. http://dx.doi.org/10.1057/fsm.2008.21

Mosavian, A. (2008). The basic principles of new pattern of Riba-free Islamic Banking, Tehran, Iran: 17th conference of Islamic Banking Publication.

Parassuraman, A., Zeithmal, V. A., \& Berry, L. (1985). A conceptual model of service quality and its implications for future research. Journal of Marketing, 49, 41-50. http://dx.doi.org/10.2307/1251430

Parassuraman, A., Zeithmal, V. A., \& Berry, L. (1988). SERVQUAL: A multiple-item scale for measuring consumer perceptions of the service. Journal of Retailing, 64(1), 12-40.

Sarmad, \& Hafez Nia. (2002). Scientific Research in Human Sciences. Samt Publications.

Woodruffe, Helen. (1995). Service Marketing, first edition, printed in UK, Bell and Bain LPT, chap1

Zeithmal V., \& Mary Jo Bitner. (1996). Service Marketing. Mc Graw Hill, Singapore

\section{Appendixes}

Table 1. Question Items

\begin{tabular}{|c|c|c|}
\hline Code & Questions Items & \multirow{2}{*}{ Dimension } \\
\hline A 01 & Interior design of the bank & \\
\hline A 02 & The facade of the bank's building & \\
\hline A 03 & Comfortable chairs & \multirow{2}{*}{ Tangibles } \\
\hline A 04 & Parking facilities near the bank & \\
\hline A 05 & Suitable waiting hall the customers & \\
\hline A 06 & Appropriate colors & \\
\hline
\end{tabular}




\begin{tabular}{|c|c|c|}
\hline A 07 & Appropriate air conditioning & \multirow{17}{*}{ Reliability } \\
\hline A 08 & Suitable forms and documents & \\
\hline A 09 & The appearance of the employees & \\
\hline A 10 & Having the same uniforms & \\
\hline A 11 & physical distance of the branch & \\
\hline A 12 & availability of virtual services & \\
\hline B 13 & Fulfillment of promises & \\
\hline B 14 & Minimum mistakes by employees & \\
\hline B 15 & Minimum mistakes in virtual services & \\
\hline B 16 & Apologizing when making mistakes & \\
\hline B 17 & Suitable ATM machines & \\
\hline B 18 & Suitable money-counter machines & \\
\hline B 19 & Providing tailor-made services & \\
\hline B 20 & Minimum waiting time in the bank & \\
\hline B 21 & Promptness of service delivery & \\
\hline B 22 & Providing diversified services & \\
\hline B 23 & Providing innovative services & \\
\hline $\mathrm{C} 24$ & The ability to answer customers' questions properly & \multirow{4}{*}{ Responsiveness } \\
\hline C 25 & The willingness to help solve customers' problems & \\
\hline C 26 & Few formalities & \\
\hline $\mathrm{C} 27$ & Provision of information & \\
\hline D 28 & Confidence in employees & \multirow{5}{*}{ Assurance } \\
\hline D 29 & Not revealing customers' personal affairs & \\
\hline D 30 & Employees' knowledge & \\
\hline D 31 & Improving customers' knowledge & \\
\hline D 32 & Courtesy & \\
\hline E 33 & Meeting unique needs of the customers & \multirow{6}{*}{ Empathy } \\
\hline E 34 & Solving unexpected problems & \\
\hline E 35 & Start time of the banks & \\
\hline E 36 & Closing time of the banks & \\
\hline E 37 & Delivering services without mid-day stops & \\
\hline E 38 & 24-hour service delivery & \\
\hline F 39 & Riba-free banking contracts & \multirow{3}{*}{ Islamic banking } \\
\hline F 40 & Setting interest rates based on Islamic principles & \\
\hline F 41 & Controlling bank facilities based on Islamic principles & \\
\hline
\end{tabular}


Table 2. Reliability of the interview

\begin{tabular}{|c|c|c|c|}
\hline Interviewee & Agreed Codes & Total number of Codes & Reliability (Percent) \\
\hline 1 & 13 & 27 & $0 / 96$ \\
\hline 2 & 16 & 35 & $0 / 91$ \\
\hline 3 & 11 & 24 & $0 / 92$ \\
\hline Total & 40 & 86 & $0 / 93$ \\
\hline
\end{tabular}

Table 3. Number of banks branches in Iran

\begin{tabular}{|c|c|c|}
\hline & Bank & Number of Branches \\
\hline 1 & Meli & 3383 \\
\hline 2 & Melat & 1780 \\
\hline 3 & Saderat & 3139 \\
\hline 4 & Tejarat & 1991 \\
\hline 5 & Refah & 1136 \\
\hline 6 & Eghtesad Novin & 205 \\
\hline 7 & Ansar & 618 \\
\hline 8 & Parsian & 206 \\
\hline 9 & Pasargad & 209 \\
\hline 10 & Sina & 260 \\
\hline & Total & 12927 \\
\hline
\end{tabular}

Table 4. Population of provinces

\begin{tabular}{|c|c|c|}
\hline & Province & Population \\
\hline 1 & Tehran & $11,228,625$ \\
\hline 2 & Khorasan Razavi & $5,515,980$ \\
\hline 3 & Isfahan & $4,499,327$ \\
\hline 4 & Fars & $4,220,721$ \\
\hline 5 & Khozestan & $4,192,598$ \\
\hline 6 & Azarbaijan Sharghi & $3,527,267$ \\
\hline 7 & Mazandaran & $2,893,087$ \\
\hline 8 & Azarbaijan Gharbi & $2,831,779$ \\
\hline 9 & Kerman & $2,584,834$ \\
\hline 10 & Gilan & $2,381,063$ \\
\hline
\end{tabular}


Table 5. Correlation Analysis

\begin{tabular}{|c|c|c|c|c|c|c|c|}
\hline 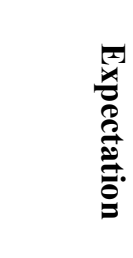 & 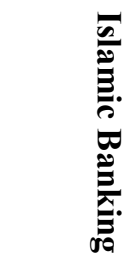 & 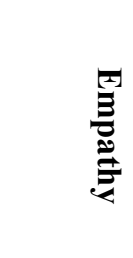 & 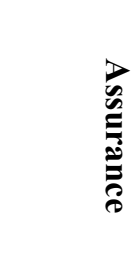 & 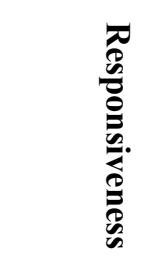 & 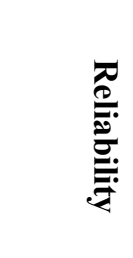 & 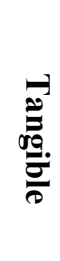 & \\
\hline $0.271^{* *}$ & $0.461^{* *}$ & $0.593^{* *}$ & $0.552^{* *}$ & $0.629 * *$ & $0.738^{* *}$ & 1 & Tangible \\
\hline $0.299^{* *}$ & $0.518^{* *}$ & $0.731^{* *}$ & $0.673^{* *}$ & $0.797 * *$ & 1 & & Reliability \\
\hline $0.243^{* *}$ & $0.495^{* *}$ & $0.694 * *$ & $0.698^{* *}$ & 1 & & & Responsiveness \\
\hline $0.318^{* *}$ & $0.401^{* *}$ & $0.744^{* *}$ & 1 & & & & Assurance \\
\hline $0.301 * *$ & $0.576^{* *}$ & 1 & & & & & Empathy \\
\hline $0.170^{* *}$ & 1 & & & & & & Islamic Banking \\
\hline 1 & & & & & & & Expectation \\
\hline
\end{tabular}

Table 6. Ratings of importance of dimensions

\begin{tabular}{|c|c|c|}
\hline & $\begin{array}{c}\text { Ratings of } \\
\text { Importance }\end{array}$ & $\begin{array}{c}\text { Ratings of meeting } \\
\text { Expectations }\end{array}$ \\
\hline Tangibles & 3.90 & 3.12 \\
\hline Reliability & 4.11 & 3.20 \\
\hline Responsiveness & 4.14 & 3.11 \\
\hline Assurance & 4.21 & 3.37 \\
\hline Empathy & 4.00 & 3.15 \\
\hline Islamic banking & 3.82 & 2.69 \\
\hline Total & 3.95 & 3.12 \\
\hline
\end{tabular}


Table 7. Final result of hypotheses of the model

\begin{tabular}{|c|c|c|c|}
\hline & \multicolumn{1}{|c|}{ Hypotheses } & Ratings & \\
\hline H 1 & $\begin{array}{r}\text { The bank customers will give high ratings to the banks in terms of } \\
\text { the importance of Tangibles. }\end{array}$ & 3.90 & Confirmed \\
\hline H 2 & $\begin{array}{r}\text { The bank customers will give high ratings to the banks in terms of } \\
\text { the importance of Reliability. }\end{array}$ & 4.11 & Confirmed \\
\hline H 3 & $\begin{array}{r}\text { The bank customers will give high ratings to the banks in terms of } \\
\text { the importance of Responsiveness. }\end{array}$ & 4.14 & Confirmed \\
\hline H 4 & $\begin{array}{r}\text { The bank customers will give high ratings to the banks in terms of } \\
\text { the importance of Empathy. }\end{array}$ & 4.21 & Confirmed \\
\hline H 5 & $\begin{array}{r}\text { The bank customers will give high ratings to the banks in terms of } \\
\text { the importance of Assurance. }\end{array}$ & 4.00 & Confirmed \\
\hline H 6 & $\begin{array}{r}\text { The bank customers will give high ratings to the banks in terms of } \\
\text { the importance of Islamic Banking. }\end{array}$ & 3.82 & Confirmed \\
\hline
\end{tabular}

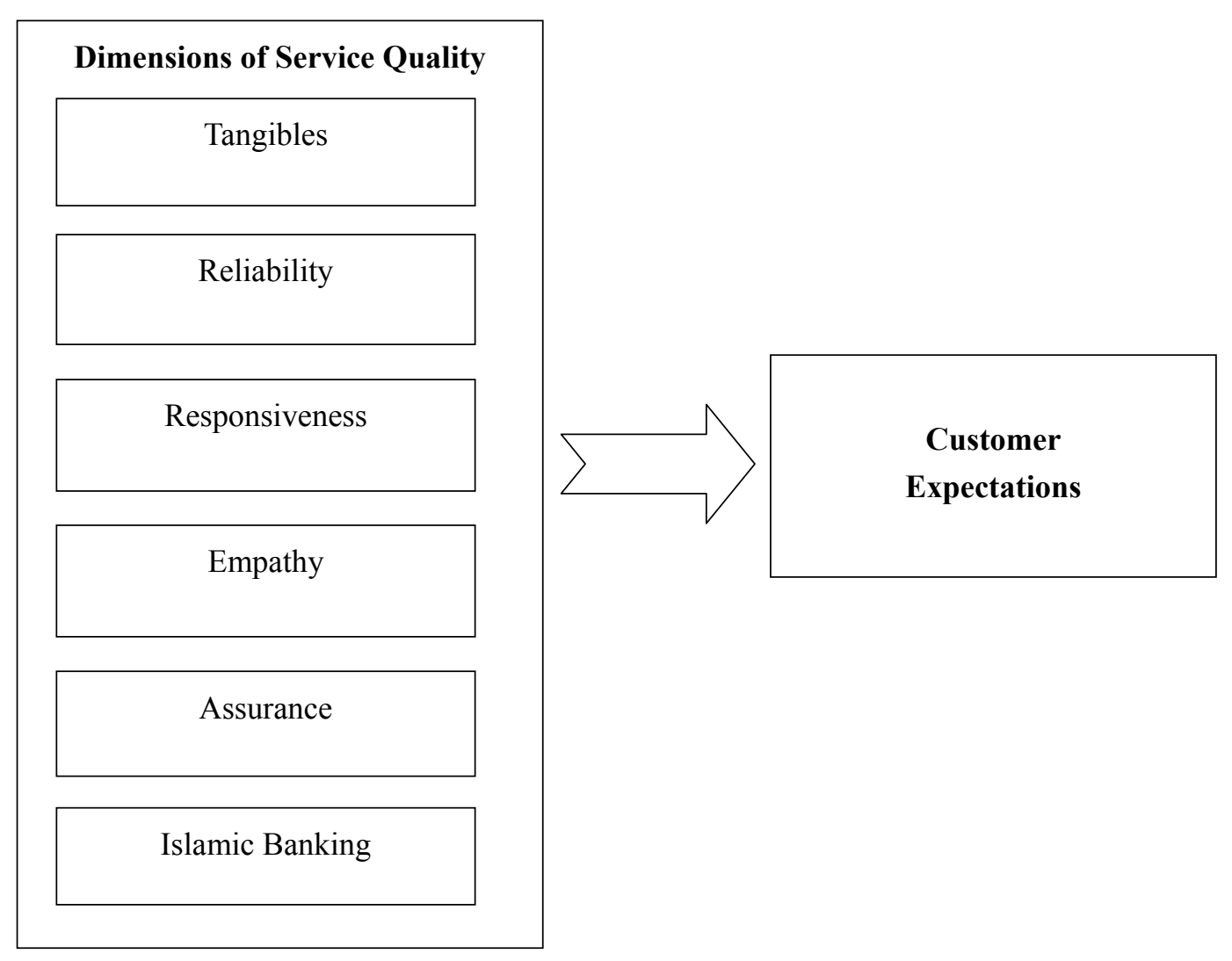

Figure 1. Survey Model 